\title{
Characterization of TLR-induced inflammatory responses in COPD and control lung tissue explants
}

This article was published in the following Dove Press journal:

International Journal of COPD

29 September 2016

Number of times this article has been viewed

\author{
Anna Pomerenke' \\ Simon R Lea' \\ Sarah Herrick ${ }^{2}$ \\ Mark A Lindsay ${ }^{3}$ \\ Dave Singh'
}

'Centre for Respiratory Medicine and Allergy, Institute of Inflammation and Repair, Manchester Academic Health Science Centre, The University of Manchester and University Hospital of South Manchester, NHS Foundation Trust, ${ }^{2}$ Institute of Inflammation and Repair, Manchester Academic Health Science Centre, University of Manchester, Manchester, ${ }^{3}$ Department of Pharmacy and Pharmacology, University of Bath, Bath, UK
Correspondence: Anna Pomerenke Centre for Respiratory Medicine and Allergy, Institute of Inflammation and Repair, Manchester Academic Health Science Centre, The University of Manchester and University Hospital of South Manchester, NHS Foundation Trust, Southmoor Road, Manchester, M23 9LT, UK

Tel +44 I6I 29I 5920

Email anna.pomerenke@gmail.com
Purpose: Viruses are a common cause of exacerbations in chronic obstructive pulmonary disease (COPD). They activate toll-like receptors (TLRs) 3, 7, and 8, leading to a pro-inflammatory response. We have characterized the responses of TLR3 and TLR7/8 in lung tissue explants from COPD patients and control smokers.

Methods: We prepared lung whole tissue explants (WTEs) from patients undergoing surgery for confirmed or suspected lung cancer. In order to mimic the conditions of viral infection, we used poly(I:C) for TLR3 stimulation and R848 for TLR7/8 stimulation. These TLR ligands were used alone and in combination. The effects of tumor necrosis factor $\alpha$ (TNF $\alpha$ ) neutralization and dexamethasone on TLR responses were examined. Inflammatory cytokine release was measured by enzyme-linked immunosorbent assay and gene expression by quantitative real-time polymerase chain reaction.

Results: WTEs from COPD patients released higher levels of pro-inflammatory cytokines compared with WTEs from smokers. Activation of multiple TLRs led to a greater than additive release of TNF $\alpha$ and CCL5. TNF $\alpha$ neutralization and dexamethasone treatment decreased cytokine release.

Conclusion: This WTE model shows an enhanced response of COPD compared with controls, suggesting an increased response to viral infection. There was amplification of innate immune responses with multiple TLR stimulation.

Keywords: COPD, poly(I:C), R848, cytokines, lung explant

\section{Introduction}

Chronic obstructive pulmonary disease (COPD) is characterized by poorly reversible airflow limitation and airway inflammation that arise in response to the inhalation of noxious particles. COPD patients can suffer with exacerbations; these events are an acute increase in symptoms beyond normal day-to-day variation. The majority of exacerbations are due to viral or bacterial respiratory infections and result in increased levels of airway and systemic inflammation. COPD exacerbations are often treated with high doses of anti-inflammatory corticosteroids. ${ }^{1}$

Viruses such as rhinovirus, adenovirus, and influenza cause COPD exacerbations. ${ }^{2}$ The viral genome is recognized by pattern recognition receptors, including toll-like receptors (TLRs) such as TLR3, TLR7, and TLR8, that are expressed on the cell surface and in the endosomes of immune and structural cells. Stimulation of these TLRs activates transcription factors, such as nuclear factor- $\kappa \mathrm{B}$ and interferon (IFN) regulatory factors, which cause increased secretion of pro-inflammatory cytokines and 
chemokines (such as tumor necrosis factor $\alpha$ [TNF $\alpha]$ and CCL5) as well as an antiviral response with increased secretion of type I and III IFNs. ${ }^{3}$

The effects of TLR activation have traditionally been studied using synthetic ligands of these receptors, such as poly(I:C) that targets TLR3, using single-cell culture systems. However, whole tissue explants (WTEs) offer the opportunity to investigate TLR-induced responses in a complex system with multiple cell types. Previous studies have demonstrated that COPD lung tissue readily responds to TLR3 and TLR4 stimulation. ${ }^{4,5}$ Viruses can activate multiple TLRs; for example, rhinovirus is recognized by both TLR3 and TLR7. ${ }^{6,7}$ Previous studies using COPD lung tissue have not assessed simultaneous stimulation of multiple TLRs.

In this study, we characterized the response of lung WTE of COPD patients to TLR3 and TLR7/8 ligands, poly(I:C), and $\mathrm{R} 848$, respectively, as a model of viral infection. The primary aim was to compare the inflammatory response of samples from COPD patients with those from controls and to investigate the effect of simultaneous stimulation with TLR3 and TLR7/8 on the inflammatory response. The secondary aim was to investigate the effect of TNF $\alpha$ inhibition and corticosteroids on these TLR-induced responses.

\section{Materials and methods}

\section{Patient information}

Lung samples were obtained from 52 patients undergoing surgery for confirmed or suspected lung cancer. All the patients were current or ex-smokers; the complete demographic details are presented in Table 1. COPD patients $(n=33)$ were diagnosed according to the Global Initiative for Chronic Obstructive Lung Disease guidelines ${ }^{1}$ and had forced expiratory volume in 1 second $\%$ predicted $<80 \%$ and ratio of forced expiratory volume in 1 second to forced vital capacity $<70 \%$. Patients without COPD were classified as smokers with normal

Table I Demographics of patients used in this study

\begin{tabular}{lll}
\hline & COPD $(\mathbf{n}=\mathbf{3 3})$ & Smokers $(\mathbf{n}=19)$ \\
\hline Sex (M/F) & $17 / 16$ & $7 / 12$ \\
Age, years & $68.7 \pm 7.9$ & $63.7 \pm 8.9$ \\
FEV & $1.84 \pm 0.60$ & $2.53 \pm 0.61$ \\
FEV,$\%$ predicted & $73.4 \pm 17.5$ & $99.3 \pm 20.0$ \\
FEV,/FVC \% ratio & $59.6 \pm 11.1$ & $75.1 \pm 0.1$ \\
Smoking status (current/ex) & $21 / 12$ & $7 / 12$ \\
Smoking history (pack-years) & $42(13-126)$ & $37(2-71)$ \\
ICS use? (yes/no) & $8 / 25$ & $0 / 19$ \\
GOLD stage (I/II/II//V) & I0/20/3/0 & NA \\
\hline
\end{tabular}

Note: Data are presented as mean \pm standard deviation or mean (range). Abbreviations: $\mathrm{FEV}_{1}$, forced expiratory volume in I second; FVC, forced vital capacity; ICS, inhaled corticosteroid; M, male; F, female; ex, ex-smoker; GOLD, Global Initiative for Chronic Obstructive Lung Disease; COPD, chronic obstructive pulmonary disease; NA, not applicable. lung function ( $\mathrm{n}=19)$. Ex-smokers were defined as individuals who had not smoked for at least 1 year. All the patients gave written informed consent, and the study was approved by the local research ethics committee (03/SM/396, NRES Committee North West - Greater Manchester South). The demographics of patient samples used in various experiments are summarized in Tables $\mathrm{S} 1$ and $\underline{\mathrm{S} 2}$.

\section{Preparation of whole tissue explants}

Human lung tissue was prepared as previously described. ${ }^{4}$ Tissue that was distal from the tumor was used. Briefly, using two sterile scalpels, $1-5 \mathrm{~g}$ of tissue was cut into small $\left(\sim 1 \mathrm{~mm}^{3}\right)$ fragments - WTEs. WTEs were rinsed with RPMI1640 medium (Sigma-Aldrich, Dorset, UK) supplemented with $10 \%$ (v/v) fetal bovine serum (Invitrogen, Paisley, UK), $100 \mathrm{U}$ penicillin/0.1 mg streptomycin (Sigma-Aldrich), and $2 \mathrm{mM} \mathrm{L-glutamine} \mathrm{(Invitrogen).} \mathrm{WTEs} \mathrm{(} 30 \pm 3 \mathrm{mg}$ ) were placed in 24-well plates with $800 \mu \mathrm{L}$ supplemented RPMI medium per well and incubated at $37^{\circ} \mathrm{C}, 5 \%(\mathrm{v} / \mathrm{v}) \mathrm{CO}_{2}$ overnight.

\section{Tissue stimulation with TLR ligands}

TLR3 (poly(I:C)) and TLR7/8 ligand (R848) stock solutions (Invivogen, San Diego, CA, USA) were diluted in supplemented RPMI-1640 medium to obtain final concentrations ranging from 0.01 to $1,000 \mu \mathrm{g} / \mathrm{mL}$, depending on the experiment. Following overnight incubation of WTE, the medium was replaced with $800 \mu \mathrm{L}$ of fresh supplemented RPMI medium, containing medium only, poly(I:C) only, R848 only, or poly(I:C) and R848 combined. Plates were then incubated at $37^{\circ} \mathrm{C}, 5 \%(\mathrm{v} / \mathrm{v}) \mathrm{CO}_{2}$ for $1,6,24$, or 48 hours. Supernatants were collected at a set time point and stored at $-20^{\circ} \mathrm{C}$, and tissue was stored in RNAlater (Invitrogen) at $-80^{\circ} \mathrm{C}$. All the conditions were performed in triplicate.

\section{TNF $\alpha$ neutralization}

Human TNF $\alpha$ Antibody (Clone \#28401) and Mouse IgG Isotype (Clone \#11711) were purchased from R\&D Systems Europe (Abingdon, UK), and the stock solutions were prepared according to the manufacturers' instructions. Following overnight incubation of WTE, the medium was replaced with $784 \mu \mathrm{L}$ of fresh supplemented RPMI medium, containing medium only, neutralizing TNF $\alpha$ antibody only $(1 \mu \mathrm{g} / \mathrm{mL})$, or control immunoglobulin $\mathrm{G}(\mathrm{IgG})$ antibody only $(1 \mu \mathrm{g} / \mathrm{mL})$. Plates were then incubated at $37^{\circ} \mathrm{C}, 5 \%(\mathrm{v} / \mathrm{v}) \mathrm{CO}_{2}$ for 1 hour. Then, $16 \mu \mathrm{L}$ of medium only, poly(I:C) only, or R848 only was added to the wells, and the plates were incubated for further 24 hours. Supernatants were collected and stored at $-20^{\circ} \mathrm{C}$, and tissue was stored in RNAlater (Invitrogen) at $-80^{\circ} \mathrm{C}$. All the conditions were performed in triplicate. 


\section{Effect of dexamethasone}

Dexamethasone was diluted in dimethyl sulfoxide (DMSO) (Sigma-Aldrich) to stock concentration of $10 \mathrm{mM}$. Following overnight incubation of WTE, the medium was replaced with $784 \mu \mathrm{L}$ of fresh supplemented RPMI medium, containing DMSO only (controls) or dexamethasone only (final concentration $1 \mu \mathrm{M})$. Plates were then incubated at $37^{\circ} \mathrm{C}, 5 \%(\mathrm{v} / \mathrm{v})$ $\mathrm{CO}_{2}$ for 1 hour. Then, $16 \mu \mathrm{L}$ of supplemented RPMI medium containing poly(I:C) only, R848 only, or poly(I:C) and R848 was added to the wells, and the plates were incubated for further 24 hours. Supernatants were collected and stored at $-20^{\circ} \mathrm{C}$ and tissue was stored in RNAlater (Invitrogen) at $-80^{\circ} \mathrm{C}$. All the conditions were performed in triplicate. Final DMSO concentration present in all conditions was $0.01 \%(\mathrm{v} / \mathrm{v})$.

\section{Enzyme-linked immunosorbent assay}

TNF $\alpha$, CCL5, and IL-6 protein levels in supernatants were measured by enzyme-linked immunosorbent assay (ELISA; R\&D Systems Europe, Abingdon, UK) according to the manufacturer's protocol. All data were adjusted for tissue weight and were presented as $\mathrm{pg} / \mathrm{mL} / \mathrm{mg}$ of tissue.

\section{Quantitative real-time polymerase chain reaction}

The levels of TNFo, CCL5, and IL-6 mRNA following TLR stimulation were measured using Taqman polymerase chain reaction (PCR) (see Supplementary materials for the detailed method).

\section{Statistics}

All the data were analyzed and plotted in GraphPad Prism 5 (GraphPad Software, Inc., San Diego, CA, USA). Normality was assessed using the Kolmogorov-Smirnov test. All TNF $\alpha$ and IL-6 ELISA data presented were parametric, whereas CCL5 ELISA data and PCR data were nonparametric. In the time course experiments, cytokine release or relative gene expression in response to a TLR ligand was compared with time-matched unstimulated controls using paired $t$-tests (or Wilcoxon signed-rank test for nonparametric data). In the experiments with different concentrations of TLR ligand, cytokine release was analyzed by one-way analysis of variance (ANOVA) with Dunnett's posttest. CCL5 was analyzed using Friedman test with Dunn's posttest. Cytokine levels after simultaneous TLR3 and TLR7/8 stimulation were compared with the cytokine levels using a single TLR agonist using paired $t$-tests or Wilcoxon signed-rank test for CCL5. The combination effect was also compared with the predicted sum (where absolute levels of cytokines released by single ligands were added together) using paired $t$-tests or Wilcoxon signed-rank test. The effects of TNF $\alpha$ neutralization were analyzed using multiple repeated ANOVA with Dunnett's posttest and Friedman with Dunn's posttest for nonparametric data. The effect of dexamethasone on cytokine release was compared with time-matched control using paired $t$-tests (or Wilcoxon signed-rank test for CCL5 data).

\section{Results}

Time course of poly(l:C)- and R848-induced cytokine release and mRNA expression

Initial experiments were performed to establish the time course of poly(I:C)- and R848-induced inflammatory response in WTE from COPD patients $(n=7)$ and smokers $(n=6)$. It was decided a priori to pool the data from both the groups for the primary aim of characterizing the time course of cytokine release (Figure 1) and mRNA production (Figure 2). Poly(I:C) $(100 \mu \mathrm{g} / \mathrm{mL})$ and R848 $(10 \mu \mathrm{g} / \mathrm{mL})$ caused timedependent increases in TNF $\alpha$, CCL5, and IL-6 release. In general, cytokine secretion was relatively low at 1 and 6 hours with higher levels at 24 and 48 hours; the only exception was high levels of TNF $\alpha$ release at 6 hours after R848 stimulation. Poly(I:C) induced higher levels of CCL5 and IL-6 compared with $\mathrm{R} 848$ reaching statistical significance at 24 and 48 hours, respectively. However, R848 was much more potent at TNF $\alpha$ induction throughout the time course (Figure S1 shows a direct comparison of $\mathrm{R} 848$ and poly(I:C)). On the basis of these results, the time point of 24 hours for maximal cytokine release was used for the subsequent experiments.

Changes in cytokine release were preceded or correlated with changes at the mRNA level. Thus, both poly(I:C) and R848 significantly upregulated cytokine mRNA expression from 6 to 48 hours after stimulation for all cytokines that were analyzed (Figure 2). There was some evidence of increased mRNA expression at 1 hour, most notably for TNF $\alpha$ after R848 stimulation. Poly(I:C) caused significantly lower TNF $\alpha$ and higher CCL5 mRNA expression than R848 (Figure S2).

Because of the limited sample size, we were unable to observe any consistent differences between COPD patients $(n=7)$ and smokers $(n=6)$ for cytokine release (Figure S3) and mRNA production (Figure S4).

\section{Poly(l:C) and R848 stimulation: comparison of COPD patients and smokers}

The response of WTE from COPD patients $(n=13)$ and smokers $(n=13)$ was compared. Cytokine secretion was TLR ligand concentration-dependent with maximal effects at $100-1,000 \mu \mathrm{g} / \mathrm{mL}$ of poly(I:C) and 1-10 $\mu \mathrm{g} / \mathrm{mL}$ of R848 (Figure 3). There was 

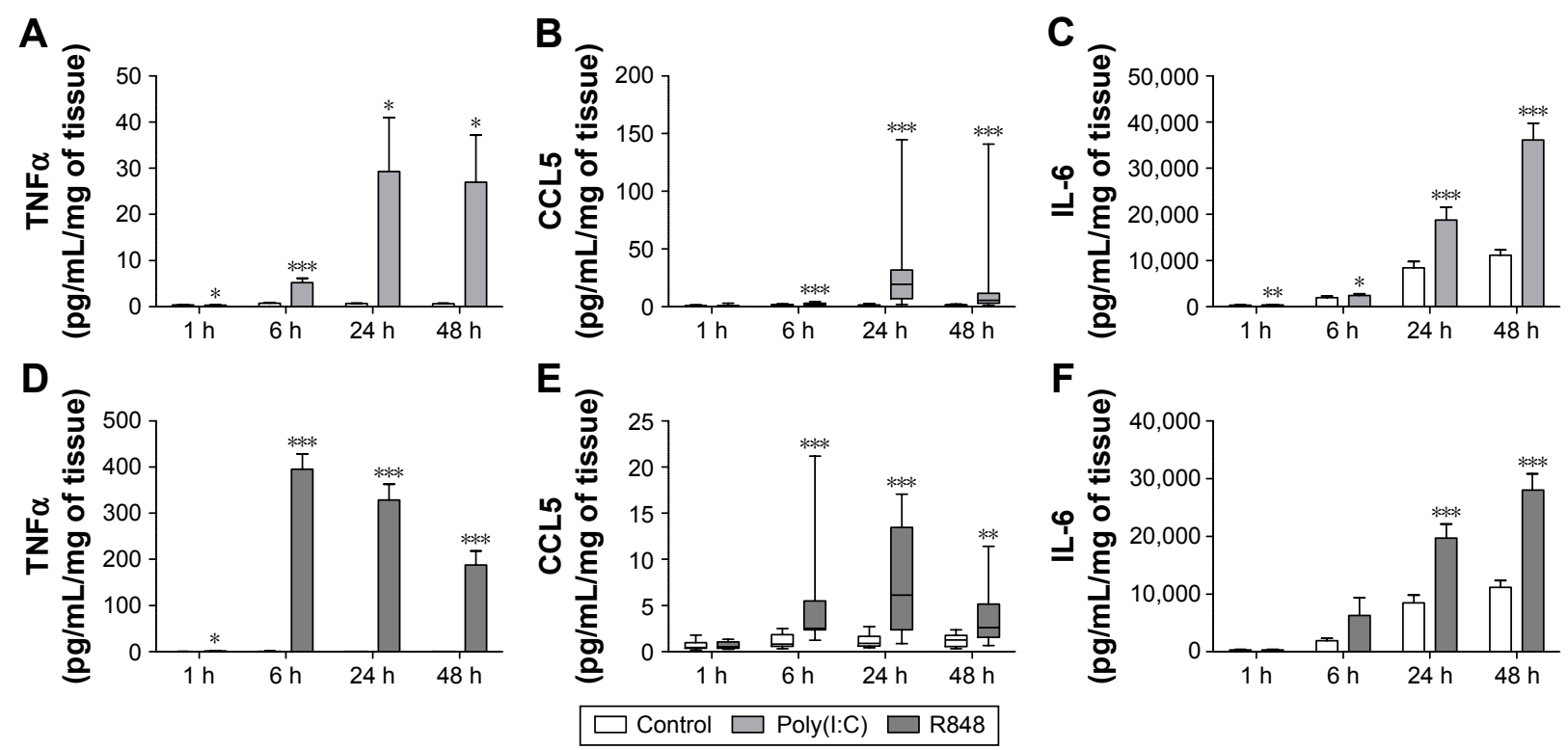

Figure I Time course of cytokine release from poly(I:C)- and R848-stimulated lung tissue.

Notes: The release of TNF $\alpha(\mathbf{A}$ and $\mathbf{D}), \operatorname{CCL} 5$ (B and E), and IL-6 (C and F) from poly $(\mathrm{I}: \mathrm{C})-(\mathrm{I} 00 \mu \mathrm{g} / \mathrm{mL})(\mathbf{A}-\mathbf{C})$ and R848-stimulated $(10 \mu \mathrm{g} / \mathrm{mL})(\mathbf{D}-\mathbf{F})$ whole tissue explants from smokers and COPD patients (pooled, $n=13$ ) were measured after I, 6, 24, and 48 hours. Data presented as mean with SEM (TNF $\alpha$ and IL-6) or median with range $(\mathrm{CCL} 5)$. $* * * * * *$ Refer to significantly above time-matched unstimulated control $(P<0.05,0.01,0.001$, respectively). Results were obtained using paired $t$-tests (TNF $\alpha$ and IL-6) and Wilcoxon matched-pairs test (CCL5).

Abbreviations: TNF $\alpha$, tumor necrosis factor $\alpha$; IL-6, interleukin 6; COPD, chronic obstructive pulmonary disease; SEM, standard error of the mean; h, hour(s).

evidence across the concentration response curve of significantly increased CCL5 release from COPD patients compared with smokers after both poly(I:C) and R848 stimulation. There was a similar pattern for TNF $\alpha$ secretion, although significant differences were observed at lower concentrations of TLR ligands. There were no differences for IL-6 release.

Current smoking caused lower TNF $\alpha$ release in the smokers group, but there was no effect in COPD patients
(Figure S5). Current smoking had no effect on CCL5 or IL-6 release.

\section{Simultaneous activation of TLR3 and TLR7/8}

Poly(I:C) $(100 \mu \mathrm{g} / \mathrm{mL})$ and R848 $(10 \mu \mathrm{g} / \mathrm{mL})$ when combined caused TNF $\alpha$ and CCL5 secretion that was greater than when the ligand was used alone in WTE from COPD
A
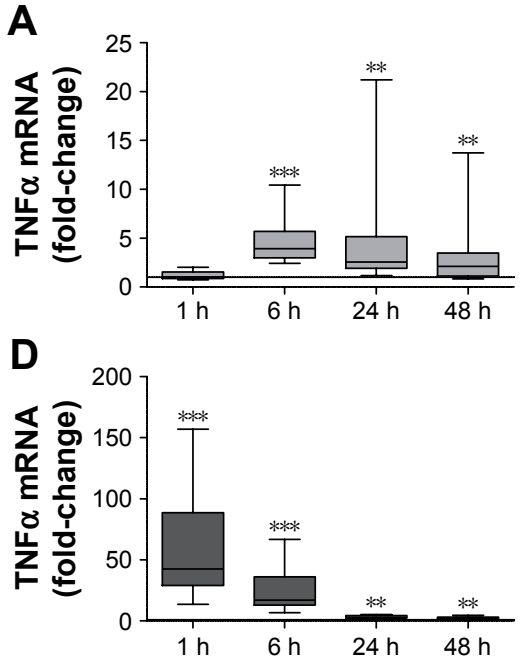

B

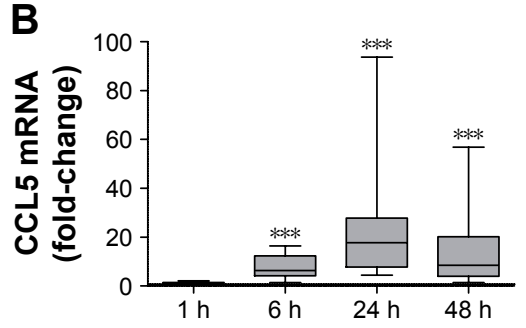

E

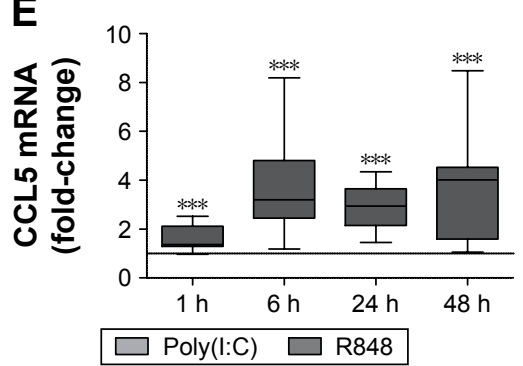

C

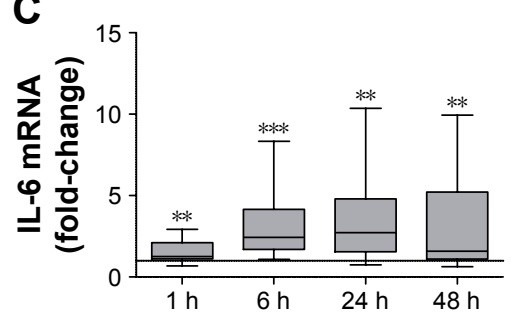

$\mathbf{F}$

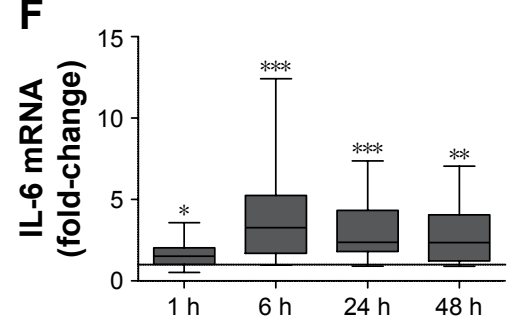

Figure 2 Time course of cytokine mRNA expression in poly(l:C)- and R848-stimulated lung tissue.

Notes: The mRNA expression of TNF $\alpha$ (A and D), CCL5 (B and E), and IL-6 (C and F) in poly(l:C)- (I00 $\mu \mathrm{g} / \mathrm{mL})(\mathbf{A}-\mathbf{C})$ and R848-stimulated (I0 $\mu g / \mathrm{mL})(\mathbf{D}-\mathbf{F})$ whole tissue explants from smokers and COPD patients (pooled, $\mathrm{n}=13$ ) was measured after I, 6, 24, and 48 hours. Data presented as median with range. ***,***Refer to significantly above time-matched unstimulated control $(P<0.05,0.01,0.001$, respectively). Horizontal line at $y=1$ represents unstimulated control. Results were obtained using a Wilcoxon matched-pairs test. Abbreviations: TNF $\alpha$, tumor necrosis factor $\alpha$; IL-6, interleukin 6; COPD, chronic obstructive pulmonary disease; h, hour(s). 

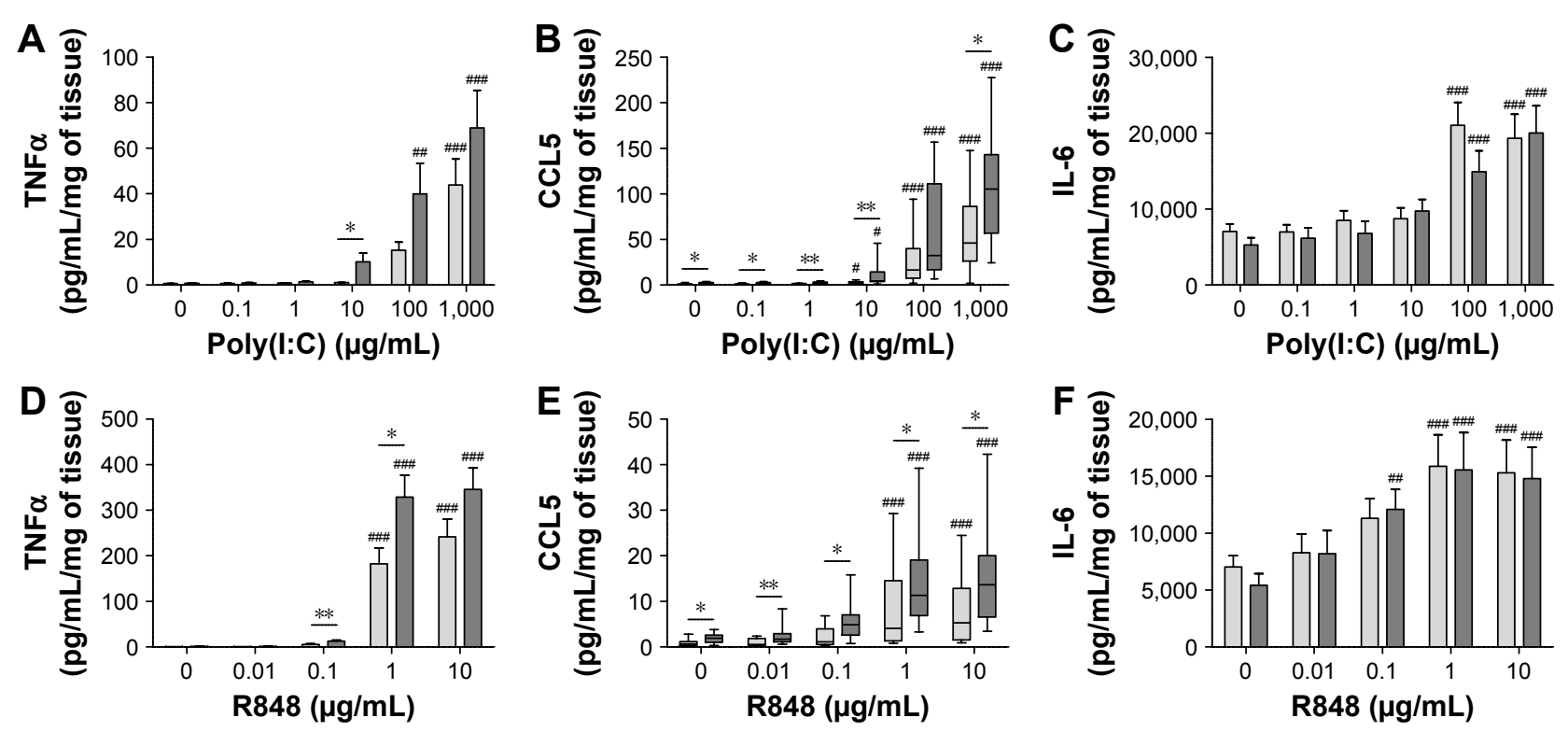

Figure 3 Concentration-dependent induction of cytokine release from poly(l:C)- and R848-stimulated lung tissue.

Notes: The release of TNF $\alpha(\mathbf{A}$ and $\mathbf{D}), \mathrm{CCL} 5$ (B and $\mathbf{E})$, and IL-6 (C and F) from poly(l:C)- (A-C) and R848-stimulated (D-F) whole tissue explants from smokers ( $\mathrm{n}=13)$

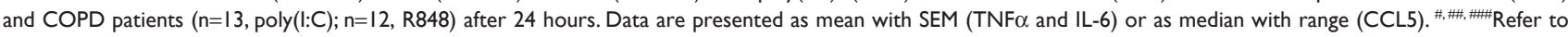
significantly above time-matched unstimulated control $(P<0.05,0.0$ I, 0.00 I, respectively). $* * *$ Refer to significant difference between subject groups $(P<0.05,0.0$ I, respectively). Results were obtained using one way ANOVA with Dunnett's post-test (TNF $\alpha$ and IL-6) and Friedman test with Dunn's post-test (CCL5) ${ }^{*} P<0.05$ and an unpaired t-test (TNF $\alpha$ and IL-6) and Mann-Whitney $U$ test (CCL5) $* P<0.05$.

Abbreviations: TNF $\alpha$, tumor necrosis factor $\alpha$; IgG, immunoglobulin G; IL-6, interleukin 6; COPD, chronic obstructive pulmonary disease; SEM, standard error of the mean.

patients $(\mathrm{n}=12)$ and smokers (n=10) (Figure 4). Furthermore, TNF $\alpha$ and CCL5 secretion was at a level that was greater than the sum of the levels induced by the ligands used alone (predicted fully additive effect). The release of IL-6 in response to poly(I:C) and R848 was greater than that when the TLR ligands were used alone but lower than the predicted fully additive effect induced by these ligands. Cytokine levels induced after the addition of poly(I:C) and R848 combined were similar in WTE from COPD patients and smokers.

\section{TNF $\alpha$ amplifies subsequent TLR3- and TLR7/8-induced pro-inflammatory response}

A TNF $\alpha$ neutralizing antibody was preincubated with COPD WTE $(n=6)$. TNF $\alpha$ neutralization caused a significant reduction in poly(I:C)-induced CCL5 and R848-induced IL-6 levels (Figure 5). Poly(I:C)-induced IL-6 and R848-induced CCL5 levels were also reduced after TNF $\alpha$ neutralization, but these changes were not statistically significant. A control antibody had no effect on cytokine release.
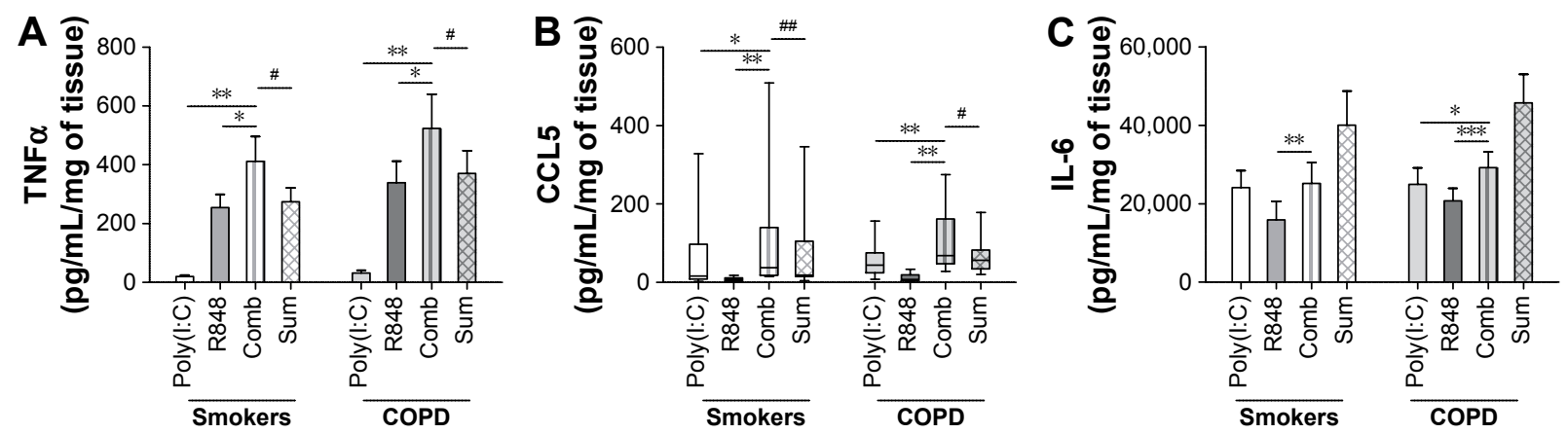

Figure 4 Effect of simultaneous activation of TLR3 and TLR7/8 on pro-inflammatory cytokine release from lung tissue.

Notes: The effect of simultaneous TLR3 and TLR7/8 activation (poly(l:C) $=100 \mu \mathrm{g} / \mathrm{mL}, \mathrm{R} 848=10 \mu \mathrm{g} / \mathrm{mL}$, respectively) on the release of TNF $\alpha$ (A), CCL5 (B), and IL-6 (C) from whole tissue explants from smokers $(n=10)$ and COPD patients $(n=12)$ after 24 hours. Data are presented as mean with SEM (TNF $\alpha$ and IL-6) or as median with range $(C C L 5)$. Sum represents the predicted additive result of poly $(\mathrm{l}: \mathrm{C})+\mathrm{R} 848$ cytokine release. $*, * * * * *$ Refer to significant difference between conditions $(P<0.025,0.005,0.0005$,

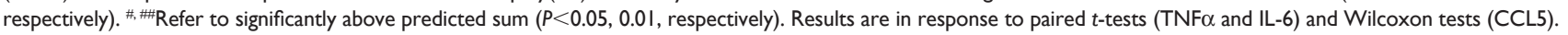
Abbreviations: TNF $\alpha$, tumor necrosis factor $\alpha$; IL-6, interleukin 6; COPD, chronic obstructive pulmonary disease; SEM, standard error of the mean; Comb, combination. 
A

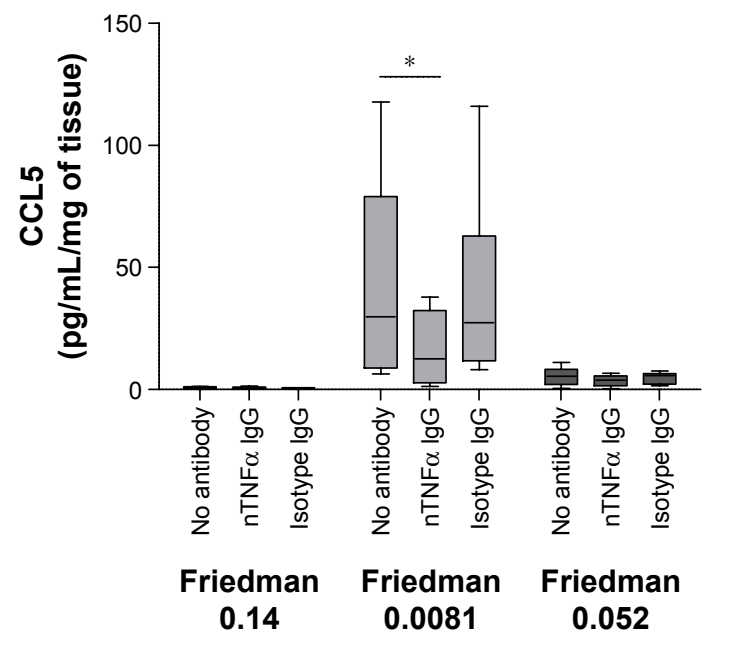

B

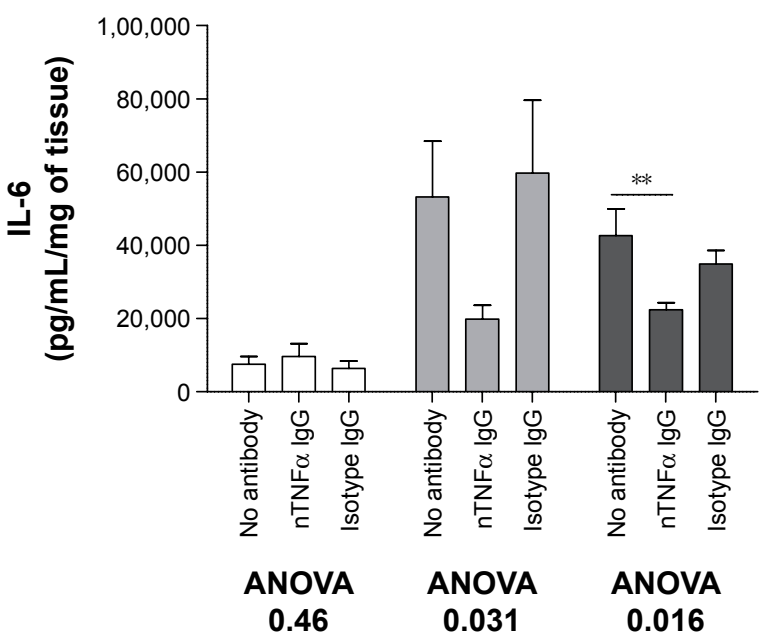

\section{$\square$ Control $\square$ Poly(l:C) $\square$ R848}

Figure 5 Effect of TNF $\alpha$ neutralization on pro-inflammatory cytokine release from lung tissue.

Notes: The effect of pre-exposure to neutralizing TNF $\alpha$ IgG antibody (nTNF $\alpha$ IgG) and control $\operatorname{lgG}$ antibody (Isotype lgG) (both I $\mu \mathrm{g} / \mathrm{mL})$ on CCL5 (A) and IL-6 (B) release from whole tissue explants from COPD patients $(\mathrm{n}=6)$ that were either unstimulated (control) or stimulated with poly $(\mathrm{l}: \mathrm{C})(\mathrm{I} 00 \mu \mathrm{g} / \mathrm{mL})$ or $\mathrm{R} 848(\mathrm{I} 0 \mu \mathrm{g} / \mathrm{mL})$ for 24 hours. Data are presented as median with range (CCL5) or mean with SEM (IL-6). ****Refer to significantly below untreated levels $(P<0.05,0.0 \mathrm{I}$, respectively). Results are in response to one way ANOVA with Dunnett's post-test (IL-6) and Friedman test with Dunn's post-test (CCL5).

Abbreviations: TNF $\alpha$, tumor necrosis factor $\alpha$; IgG, immunoglobulin G; IL-6, interleukin 6; COPD, chronic obstructive pulmonary disease; SEM, standard error of the mean; ANOVA, analysis of variance.

\section{Corticosteroid inhibition of cytokines}

WTE from COPD patients $(\mathrm{n}=6)$ were treated with dexamethasone $(1 \mu \mathrm{M})$ prior to stimulation with poly(I:C) alone, R848 alone, or both TLR ligands simultaneously (Figure 6). Dexamethasone significantly decreased cytokine release in the majority of conditions, ranging from $52 \%$ to $82 \%$ at 24 hours.

\section{Discussion}

We have characterized the cytokine response of COPD WTE to synthetic viral TLR stimuli. Poly(I:C) and R848 both caused increased TNF $\alpha$ and CCL5 secretion in COPD patients compared with smokers. This increased inflammatory response could contribute to the pathophysiology of COPD exacerbations after viral infection. Combination of these TLR ligands produced greater responses than either ligand alone. TNF $\alpha$ had an important role in promoting the secretion of other cytokines, and we show that these responses are partially inhibited by corticosteroids.

Increased cytokine secretion has been reported in COPD patients compared with controls using TLR4-stimulated
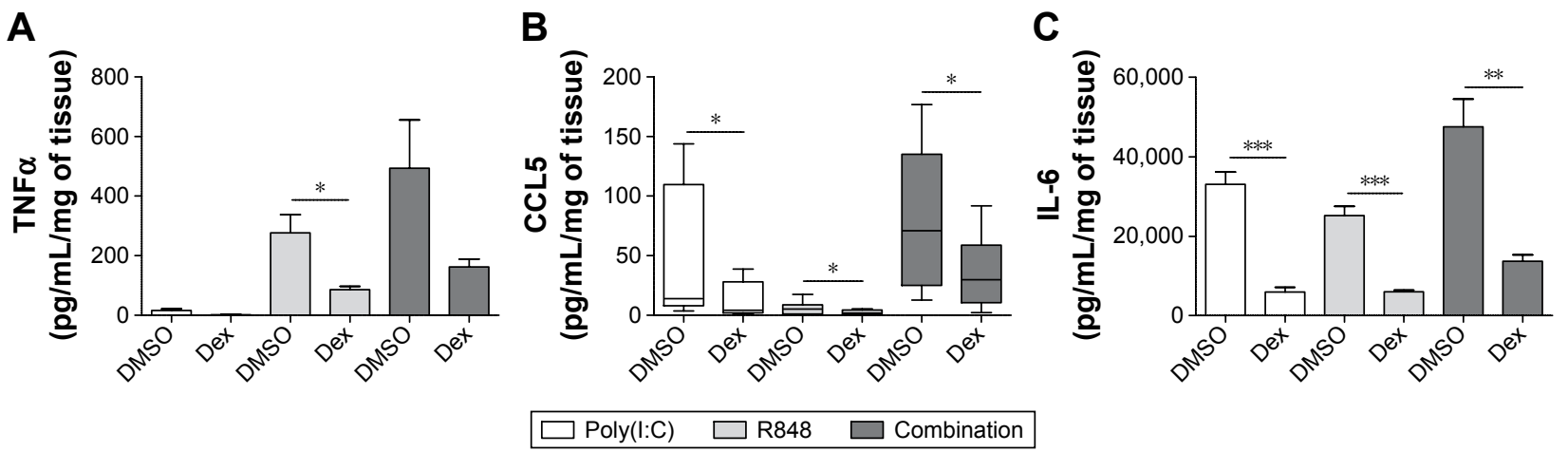

Figure 6 Effect of dexamethasone on pro-inflammatory cytokine release from TLR-stimulated lung tissue.

Notes: The effect of dexamethasone (I $\mu \mathrm{M})$ on poly(l:C)- $(100 \mu \mathrm{g} / \mathrm{mL})$, R848- $(10 \mu \mathrm{g} / \mathrm{mL})$, and combination-induced release of TNF $\alpha(\mathbf{A})$, CCL5 $(\mathbf{B})$, and IL-6 $($ C) after 24 hours from whole tissue explants from COPD patients $(\mathrm{n}=6)$. Data are presented as mean with SEM (TNF $\alpha$ and IL-6) or median with range (CCL5). ***,***Refer to significantly below DMSO control $(P<0.05,0.01,0.00$ I, respectively). Results are in response to paired $t$-tests (TNF $\alpha$ and IL-6) and Wilcoxon tests (CCL5).

Abbreviations: TNF $\alpha$, tumor necrosis factor $\alpha$; IL-6, interleukin 6; COPD, chronic obstructive pulmonary disease; SEM, standard error of the mean; Dex, dexamethasone; DMSO, dimethyl sulfoxide. 
WTE. ${ }^{4}$ We observed similar findings using different TLR ligands relevant to viral infection. Interestingly, differences in cytokine release between smokers and COPD patients were not observed when both the TLR agonists were used simultaneously. This might signify near maximal inflammation being achieved in this tissue model, making it difficult to observe differences between groups.

Viral infections are likely to trigger the activation of multiple pattern recognition receptors. The combination of poly(I:C) and R848 caused TNF $\alpha$ and CCL5 secretion that was greater than the predicted fully additive effect of combining the TLR ligands. This raises the possibility that this combination of TLR ligands caused a synergistic proinflammatory effect. However, IL-6 was not released in such a synergistic manner. This may be due to IL-6 levels being already high when stimulated by one ligand. Perhaps using lower ligand concentrations for this experiment would reveal a different pattern for IL-6, and it would be important to perform experiments using different TLR ligand concentrations in combination in order to confirm this possibility of synergism. Others have also examined multiple TLR activation in different models, eg, monocyte-derived dendritic cells and macrophages, and also have observed synergistic release of various cytokines (including TNF $\alpha$ and IL-6) ${ }^{8-13}$ However, synergy in cytokine release was not observed in monocyte-derived macrophages. ${ }^{10}$

TLR3 and TLR7/8 use different molecular adaptors to activate downstream signaling pathways: TLR3 signals via TRIF, whereas TLR7 and TLR8 use MyD88. ${ }^{14}$ Previous studies examining simultaneous activation of different TLRs have demonstrated that activation of both MyD88- and TRIF-dependent pathways results in synergistic cytokine release. ${ }^{10,15}$ The exact mechanisms are still to be elucidated, but the crosstalk between multiple pro-inflammatory pathways downstream of TLRs appears to play a role in this process. ${ }^{10}$

Viral infections are a common cause of COPD exacerbations and are associated with increased airway inflammation in COPD patients. ${ }^{16-18}$ The additive, and possibly synergistic, cytokine production reported here are mechanisms that are likely to contribute to the excessive airway inflammation during viral infections, predisposing to other harmful pathophysiological effects such as tissue damage. On the other hand, the host immune response is required for the recruitment of cells responsible for pathogen clearance. A variety of mechanism are involved in viral clearance, ${ }^{19}$ and our investigations focus more on immune pathways that could cause excessive inflammation.
There is evidence of attenuation of TLR-induced cytokine release in cells pretreated with cigarette smoke extract or cells derived from smokers. ${ }^{20-22}$ For example, Metcalfe et al ${ }^{20}$ showed that acute cigarette smoke extract exposure decreased TLR-induced cytokine release from alveolar macrophages while Chen et $\mathrm{al}^{22}$ observed attenuation in TLR2- and TLR4induced cytokine release from alveolar macrophages from smokers compared with nonsmokers. We observed that the TLR7/8- and TLR3-induced TNF $\alpha$ response was attenuated by current smoking in the smokers group but that there was no effect in COPD patients. Furthermore, there was no effect of current smoking on CCL5 and IL-6. One should be cautious when interpreting this subanalysis with small sample sizes. Overall, we feel that current smoking had a minimal impact on the data presented.

$\mathrm{TNF} \alpha$ is implicated in inflammatory responses in COPD. ${ }^{23-25}$ Multiple cell types are able to release and respond to $\mathrm{TNF} \alpha$, including epithelial cells and macrophages. ${ }^{26-28}$ We found that a neutralizing TNF $\alpha$ antibody attenuated TLR3- and TLR7/8-induced release of CCL5 and IL-6. Similar observations were made by Hackett et al using lung tissue exposed to lipopolysaccharide (LPS). ${ }^{4}$ These data suggest that TNF $\alpha$ is required for maximal pro-inflammatory responses in the lung tissue. However, anti-TNF $\alpha$ treatment did not have any benefit in COPD patients. ${ }^{29,30}$ It is possible that TNF $\alpha$ plays a role as an amplifier of TLR signaling during infection in COPD patients, rather than having a significant role in the stable clinical state.

Corticosteroids are commonly used in COPD therapy, either as regular inhaled treatment or as short courses of oral treatment during exacerbations. ${ }^{1}$ We showed that dexamethasone partially inhibited the release of all three pro-inflammatory cytokines measured. Similarly, other in vitro studies have shown that corticosteroids partially suppress pro-inflammatory cytokine release from different cell types, including alveolar macrophages, monocyte-derived macrophages, and primary bronchial epithelial cells. ${ }^{26,31-33}$ Our observations suggest a partial anti-inflammatory effect by corticosteroids on COPD lung tissue during viral TLR stimulation.

Activation of TLR7 is being investigated as a therapeutic option for asthma, as there is evidence that this skews the immune response away from a Th2 profile and toward a Th1 profile, which may be useful for suppressing allergic inflammation. ${ }^{34,35}$ Our research was not focused on this question, but we show how TLR7 stimulation may affect COPD lung immune responses. It is possible that TLR antagonists may be beneficial in COPD patients to limit inflammation 
associated with smoking, as various TLRs are implicated in pro-inflammatory responses to cigarette smoke. ${ }^{36-40}$ However, since TLRs play a role in infection, using TLR antagonists during infection could lead to increased pathogen proliferation. ${ }^{41} \mathrm{~A}$ balanced approach to TLR therapeutics is required to limit tissue-destructive inflammation without compromising pathogen clearance. ${ }^{42}$

There were some practical limitations to our study. The vast majority of patients undergoing cancer surgery were current or ex-smokers, so it was difficult to recruit lifelong nonsmokers as a control group. Additionally, it is possible that the presence of cancer may influence the immune response, even though we used tumor-free tissue.

In summary, we have demonstrated that COPD WTE showed a greater pro-inflammatory response to TLR3 or TLR7/8 activation than control smokers. Interestingly, simultaneous stimulation of these TLRs caused innate immune responses that were at least additive. The model described here can be further used to model and dissect the COPD immune response during viral infection, for the purpose of identifying molecular pathways suitable for pharmacological intervention.

\section{Acknowledgments}

This study was funded by the Biotechnology and Biological Sciences Research Council and Pfizer. This report is an independent research supported by the National Institute for Health Research Respiratory and Allergy Clinical Research Facility at University Hospital of South Manchester NHS Foundation Trust. The views expressed in this publication are those of the author(s) and not necessarily those of the NHS, the National Institute for Health Research, or the Department of Health.

\section{Disclosure}

AP, SL, SH, and ML report no conflicts of interest in this work. DS has received sponsorship to attend international meetings, honoraria for lecturing and attending advisory boards, and research grants from various pharmaceutical companies, including Almirall, AstraZeneca, Boehringer Ingelheim, Chiesi, CIPLA, Forest, Genetech, GlaxoSmithKline, Merck, Novartis, Pfizer, and Takeda.

\section{References}

1. Global Initiative for Chronic Obstructive Pulmonary Disease. Global Strategy for the Diagnosis, Management, and Prevention of Chronic Obstructive Pulmonary Disease; 2015. Available from: http://www. goldcopd.org/uploads/users/files/GOLD_Report_2015_Sept2.pdf. Accessed October 10, 2015.

2. Wedzicha JA. Role of viruses in exacerbations of chronic obstructive pulmonary disease. Proc Am Thorac Soc. 2004;1(2):115-120.
3. O'Neill LAJ, Golenbock D, Bowie AG. The history of toll-like receptors - redefining innate immunity. Nat Rev Immunol. 2013;13(6): 453-460.

4. Hackett T-L, Holloway R, Holgate S, Warner J. Dynamics of proinflammatory and anti-inflammatory cytokine release during acute inflammation in chronic obstructive pulmonary disease: an ex vivo study. Respir Res. 2008;9:47.

5. Cooper PR, Lamb R, Day ND, et al. TLR3 activation stimulates cytokine secretion without altering agonist-induced human small airway contraction or relaxation. Am J Physiol Lung Cell Mol Physiol. 2009;297(3):L530-L537.

6. Hewson CA, Jardine A, Edwards MR, Laza-Stanca V, Johnston SL. Toll-like receptor 3 is induced by and mediates antiviral activity against rhinovirus infection of human bronchial epithelial cells. J Virol. 2005; 79(19): 12273-12279.

7. Triantafilou K, Vakakis E, Richer EAJ, Evans GL, Villiers JP, Triantafilou M. Human rhinovirus recognition in non-immune cells is mediated by toll-like receptors and MDA-5, which trigger a synergetic pro-inflammatory immune response. Virulence. 2011;2(1):22-29.

8. Bohnenkamp HR, Papazisis KT, Burchell JM, Taylor-Papadimitriou J. Synergism of toll-like receptor-induced interleukin- $12 \mathrm{p} 70$ secretion by monocyte-derived dendritic cells is mediated through p38 MAPK and lowers the threshold of T-helper cell type I responses. Cell Immunol. 2007; 247(2):72-84

9. Mäkelä SM, Osterlund P, Julkunen I. TLR ligands induce synergistic interferon-beta and interferon-lambdal gene expression in human monocyte-derived dendritic cells. Mol Immunol. 2011;48(4):505-515.

10. Mäkelä SM, Strengell M, Pietilä TE, Österlund P, Julkunen I. Multiple signaling pathways contribute to synergistic TLR ligand-dependent cytokine gene expression in human monocyte-derived macrophages and dendritic cells. J Leukoc Biol. 2009;85(4):664-672.

11. Morris GE, Parker LC, Ward JR, et al. Cooperative molecular and cellular networks regulate toll-like receptor-dependent inflammatory responses. FASEB J. 2006;20(12):2153-2155.

12. Roelofs MF, Joosten LA, Abdollahi-Roodsaz S, et al. The expression of toll-like receptors 3 and 7 in rheumatoid arthritis synovium is increased and costimulation of toll-like receptors 3, 4, and 7/8 results in synergistic cytokine production by dendritic cells. Arthritis Rheum. 2005; 52(8):2313-2322.

13. Suet Ting Tan R, Lin B, Liu Q, et al. The synergy in cytokine production through MyD88-TRIF pathways is co-ordinated with ERK phosphorylation in macrophages. Immunol Cell Biol. 2013;91(5):377-387.

14. Yamamoto M, Sato S, Hemmi H, et al. Role of adaptor TRIF in the MyD88-independent toll-like receptor signaling pathway. Science. 2003;301:640-643.

15. Ouyang X, Negishi H, Takeda R, Fujita Y, Taniguchi T, Honda K. Cooperation between MyD88 and TRIF pathways in TLR synergy via IRF5 activation. Biochem Biophys Res Commun. 2007;354(4): 1045-1051.

16. Dai MY, Qiao JP, Xu YH, Fei GH. Respiratory infectious phenotypes in acute exacerbation of COPD: an aid to length of stay and COPD Assessment Test. Int J Chron Obstruct Pulmon Dis. 2015;10:2257-2263.

17. Wedzicha JA. Mechanisms of chronic obstructive pulmonary disease exacerbations. Ann Am Thorac Soc. 2015;12(Suppl 2):S157-S159.

18. Hewitt R, Farne H, Ritchie A, Luke E, Johnston SL, Mallia P. The role of viral infections in exacerbations of chronic obstructive pulmonary disease and asthma. Ther Adv Respir Dis. 2015. Epub 2015 Nov 26.

19. Yoo J-K, Kim TS, Hufford MM, Braciale TJ. Viral infection of the lung: host response and sequelae. J Allergy Clin Immunol. 2013;132(6): $1263-1276$

20. Metcalfe HJ, Lea S, Hughes D, Khalaf R, Abbott-Banner K, Singh D. Effects of cigarette smoke on toll-like receptor (TLR) activation of chronic obstructive pulmonary disease (COPD) macrophages. Clin Exp Immunol. 2014;176(3):461-472.

21. Todt JC, Freeman CM, Brown JP, et al. Smoking decreases the response of human lung macrophages to double-stranded RNA by reducing TLR3 expression. Respir Res. 2013;14:33. 
22. Chen H, Cowan MJ, Hasday JD, Vogel SN, Medvedev AE. Tobacco smoking inhibits expression of proinflammatory cytokines and activation of IL-1R-associated kinase, p38, and NF- $\mathrm{KB}$ in alveolar macrophages stimulated with TLR2 and TLR4 agonists. J Immunol. 2007;179(9):6097-6106.

23. Pedroza M, Schneider DJ, Karmouty-Quintana H, et al. Interleukin-6 contributes to inflammation and remodeling in a model of adenosine mediated lung injury. PLoS One. 2011;6(7):e22667.

24. Vernooy JH, Küçükaycan M, Jacobs JA, et al. Local and systemic inflammation in patients with chronic obstructive pulmonary disease. Am J Respir Crit Care Med. 2002;166(9):1218-1224.

25. Yasuda N, Gotoh K, Minatoguchi S, et al. An increase of soluble Fas, an inhibitor of apoptosis, associated with progression of COPD. Respir Med. 1998;92(8):993-999.

26. Armstrong J, Sargent C, Singh D. Glucocorticoid sensitivity of lipopolysaccharide-stimulated chronic obstructive pulmonary disease alveolar macrophages. Clin Exp Immunol. 2009;158(1):74-83.

27. Schall TJ, Lewis M, Koller KJ, et al. Molecular cloning and expression of a receptor for human tumor necrosis factor. Cell. 1990;61(2):361-370.

28. Wark PAB, Bucchieri F, Johnston SL, et al. IFN- $\gamma$-induced protein 10 is a novel biomarker of rhinovirus-induced asthma exacerbations. J Allergy Clin Immunol. 2007;120(3):586-593.

29. van der Vaart H, Koëter GH, Postma DS, Kauffman HF, ten Hacken NHT. First study of infliximab treatment in patients with chronic obstructive pulmonary disease. Am J Respir Crit Care Med. 2005;172(4):465-469.

30. Rennard SI, Fogarty C, Kelsen S, et al. The safety and efficacy of infliximab in moderate to severe chronic obstructive pulmonary disease. Am J Respir Crit Care Med. 2007;175(9):926-934.

31. Lea S, Plumb J, Metcalfe H, et al. The effect of peroxisome proliferatoractivated receptor- $\gamma$ ligands on in vitro and in vivo models of COPD. Eur Respir J. 2014;43(2):409-420.

32. Kent LM, Smyth LJC, Plumb J, et al. Inhibition of lipopolysaccharidestimulated chronic obstructive pulmonary disease macrophage inflammatory gene expression by dexamethasone and the $\mathrm{p} 38$ mitogen-activated protein kinase inhibitor $\mathrm{N}-$ cyano- $\mathrm{N}^{\prime}-(2-\{[8-(2,6-$ difluorophenyl)-4-(4fluoro-2-methylphenyl)-7-oxo-7,8-dihydropyrido[2,3-d] pyrimidin2-yl]amino \}ethyl)guanidine (SB706504). J Pharmacol Exp Ther. 2009;328(2):458-468.
33. Heijink I, van Oosterhout A, Kliphuis N, et al. Oxidant-induced corticosteroid unresponsiveness in human bronchial epithelial cells. Thorax. 2013;69(1):5-13.

34. Zuo L, Lucas K, Fortuna CA, Chuang CC, Best TM. Molecular regulation of toll-like receptors in asthma and COPD. Front Physiol. 2015; $6: 312$.

35. Drake MG, Kaufman EH, Fryer AD, Jacoby DB. The therapeutic potential of toll-like receptor 7 stimulation in asthma. Inflamm Allergy Drug Targets. 2012;11(6):484-491.

36. Pace E, Ferraro M, Siena L, et al. Cigarette smoke increases toll-like receptor 4 and modifies lipopolysaccharide-mediated responses in airway epithelial cells. Immunology. 2008;124(3):401-411.

37. Karimi K, Sarir H, Mortaz E, et al. Toll-like receptor-4 mediates cigarette smoke-induced cytokine production by human macrophages. Respir Res. 2006;7:66.

38. Droemann D, Goldmann T, Tiedje T, Zabel P, Dalhoff K, Schaaf B Toll-like receptor 2 expression is decreased on alveolar macrophages in cigarette smokers and COPD patients. Respir Res. 2005;6:68

39. Mortaz E, Adcock IM, Ito K, Kraneveld AD, Nijkamp FP, Folkerts G Cigarette smoke induces CXCL8 production by human neutrophils via activation of TLR9 receptor. Eur Respir J. 2010;36(5):1143-1154.

40. Wortham BW, Eppert BL, Flury JL, Morgado Garcia S, Borchers MT. TLR and NKG2D signaling pathways mediate CS-induced pulmonary pathologies. PLoS One. 2013;8(10):e78735.

41. Wieland CW, Florquin S, Maris NA, et al. The MyD88-dependent, but not the MyD88-independent, pathway of TLR4 signaling is important in clearing nontypeable Haemophilus influenzae from the mouse lung. J Immunol. 2005;175(9):6042-6049.

42. Bezemer GF, Sagar S, van Bergenhenegouwen J, et al. Dual role of toll-like receptors in asthma and chronic obstructive pulmonary disease. Pharmacol Rev. 2012;64(2):337-358.
International Journal of COPD

\section{Publish your work in this journal}

The International Journal of COPD is an international, peer-reviewed journal of therapeutics and pharmacology focusing on concise rapid reporting of clinical studies and reviews in COPD. Special focus is given to the pathophysiological processes underlying the disease, intervention programs, patient focused education, and self management protocols.

\section{Dovepress}

This journal is indexed on PubMed Central, MedLine and CAS. The manuscript management system is completely online and includes a very quick and fair peer-review system, which is all easy to use. Visit http://www.dovepress.com/testimonials.php to read real quotes from published authors. 